\title{
Partial monosomy for chromosome 22 in a patient with $\operatorname{del}(22)($ pter $\rightarrow$ q13.1::q13.33 $\rightarrow$ qter $)$
}

\author{
D R Romain, J Goldsmith, H Cairney, L M Columbano-Green, R H Smythe, R G Parfitt
}

\begin{abstract}
An 18 month old girl with partial monosomy for the long arm of chromosome 22 is described. The karyotype was 46,XX,del(22)(pter $\rightarrow$ q13.1::q13.33 $\rightarrow$ qter). To our knowledge this is the first report of monosomy for this specific segment of chromosome 22. Clinical features include developmental delay in all areas, hypotonia, macrosomia, full cheeks, eyebrows, and eyelids, mild epicanthus, wide nasal bridge, long philtrum, and thick lower lip. Parental chromosome studies were normal.
\end{abstract}

\section{Case report}

The proband was an 18 month old girl born to a 34 year old mother and a 28 year old father. Pregnancy was uneventful with birth weight $3600 \mathrm{~g}$ at 42 weeks' gestation. At birth she had a positional talipes, but no other anomalies were noted. At the age of 11 months her head circumference was $44.6 \mathrm{~cm}$ (50th centile), her weight was $9 \mathrm{~kg}$ (50th centile), and her length was $79 \mathrm{~cm}$ (97th centile). She had a rather unusual, low pitched, growling cry. There was a small umbilical hernia and coccygeal dimple. Other than a constant running nose and dribbling, her general physical appearance was unremarkable. At 18 months a Denver developmental assessment showed delays in all areas, particularly in fine motor and gross motor development. She is hypotonic, is not yet walking, and is unable to feed herself. Her hearing is thought to be normal, although she has only three or four recognisable words. Her length is now $87 \mathrm{~cm}$ (just above the 97 th centile), weight $11.4 \mathrm{~kg}$, and head circumference $47.5 \mathrm{~cm}$ (both just above the $50 \mathrm{th}$ centile). She is a floppy child with a relatively

Cytogenetics Laboratory, Laboratory Services, Wellington Hospital, Wellington, New Zealand.

D R Romain, H Cairney, L M Columbano-Green, R H Smythe, R G Parfitt

Department of Paediatrics, Wanganui Hospital, Wanganui, New Zealand.

J Goldsmith

Correspondence to D R Romain.

Received for publication 28 February 1990.

Accepted for publication 20 March 1990. expressionless face, full cheeks and eyebrows, fullness of the upper eyelid, ptosis, and mild epicanthus.

There is no obvious strabismus. She has a wide nasal bridge with short columella and slightly long philtrum, a V shaped upper lip, and a thick, pronounced lower lip (fig 1). She has prominent auricles with some transverse creases on the lobes. The external genitalia are normal although the labia majora are rather prominent. Full blood count, thyroid function, serum amino acids, and routine biochemistry screen were normal. Cytogenetic studies showed a complement of 46,XX,del(22)(pter $\rightarrow$ q13.1::q13.33 $\rightarrow$ qter) (fig 2). Parental chromosome studies were normal.

\section{Discussion}

Partial monosomy for chromosome 22 is associated with ring chromosome 22 and frequently with the DiGeorge malformation. ${ }^{1}$ Deletions of other segments of 22q include 22q12 $\rightarrow$ qter reported by Watt et al, ${ }^{2}$ 22(pter $\rightarrow$ q12:) described by Kirshenbaum et $a l^{3}$ and 22q13.31 reported by Herman $e t a l^{4}$ in a patient with the Goldenhar complex.

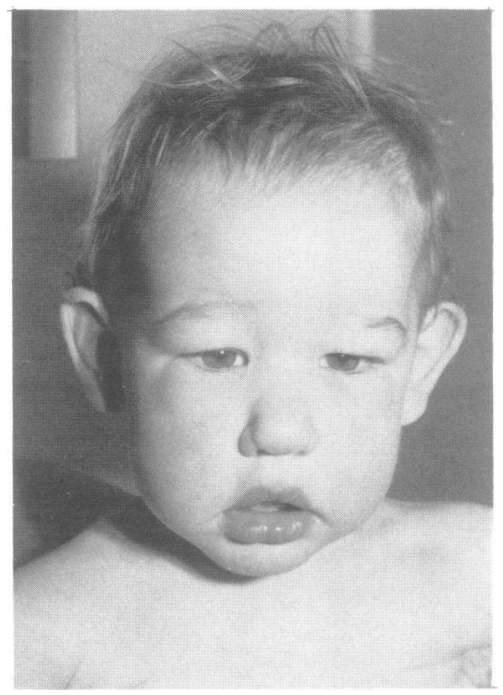

Figure 1 Frontal facial appearance of index case. 


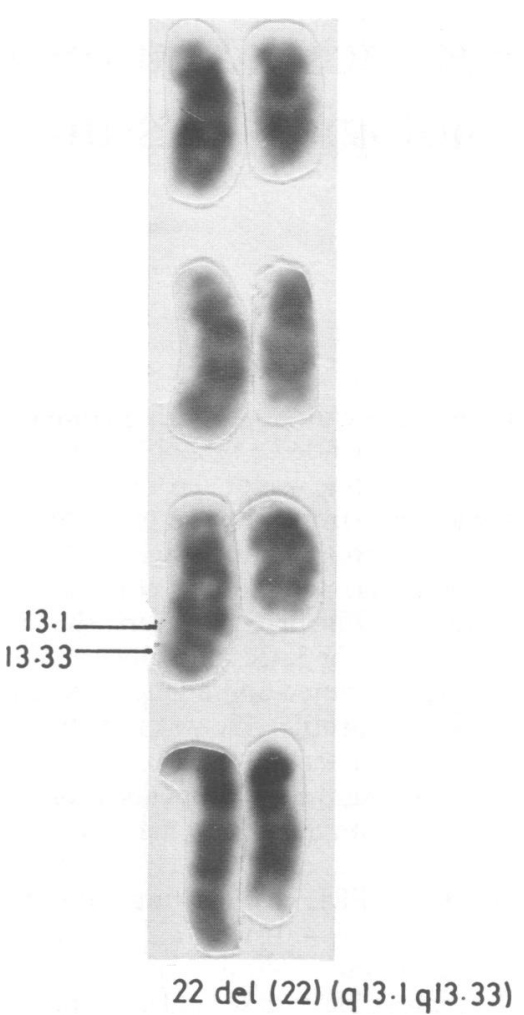

Figure 2 High resolution $G$ banded examples of del $(22 q)$.

Clinically, as well as overall developmental delay, our patient shares many of the features described in the case of Watt et al, ${ }^{2}$ namely full cheeks and eyebrows, epicanthic folds, slightly long philtrum, wide, flat nasal bridge, and long trunk. These findings are also frequently seen in $r(22)$ patients who show, in addition, like our case, muscular hypotonia, thick, full lips, ptosis, and large ears with poorly folded helix.
Comparison of our patient with the one of Kirshenbaum $e t a l^{s}$ is more difficult as no high resolution chromosome banding studies were presented in that report. Nevertheless, from the information available the case appears similar, presenting with developmental delay, epicanthic folds, and other characteristics cited by the authors as observed in G-deletion syndrome II. ${ }^{5}$

Various normal and disease genes have now been mapped to the $22 \mathrm{q} 13 \rightarrow \mathrm{qter}$ region, namely the meningioma chromosome region, $\beta$-galactosidase- 2 , arylsulphatase A, NAOH-diaphorase-1, and preproacrosin (ACK) ${ }^{6}$ It would be of interest in such cases as ours to study the enzyme arylsulphatase A (ARSA) activity for example. A reduced activity would be expected, consistent with a gene dosage effect, owing to deletion of one of the two homölogous genes. ${ }^{7}$

We thank Mrs $\mathrm{H}$ Lawton for typing the manuscript and the Audiovisual Unit of the Wellington Clinical School for assistance with the illustrations.

1 Dallapiccola B, Marino B, Giannottia A, Valorani G. DiGeorge anomaly associated with partial deletion of chromosome 22 . Report of a case with $\mathrm{X} / 22$ translocation and review of the literature. Ann Genet (Paris) 1989;32:92-6.

2 Watt JL, Olson IA, Johnston AW, Ross HS, Couzin DA, Stephen GS. A familial pericentric inversion of chromosome 22 with a recombinant subject illustrating a 'pure' partial monosomy syndrome. F Med Genet 1985;22:283-7.

3 Kirshenbaum G, Chmura M, Rhone DP. Long arm deletion of chromosome 22. F Med Genet 1988;25:780.

4 Herman GE, Greenberg F, Ledbetter DH. Multiple congenital anomaly/mental retardation (MCA/MR) syndrome with Goldenhar complex due to terminal del (22q). Am f Med Genet 1988;29:909-15.

5 Warren RJ, Rimoin DL, Summitt RL. Identification by fluorescent microscopy of the abnormal chromosomes associated with the G-deletion syndrome. Am F Hum Genet 1973;25:77-81.

6 Adham IM, Grzeschik KH, Geurtsvankessel AHM, Engel W. The gene encoding the human preproacrosin (ACR) maps to the q13 $\rightarrow$ qter region on chromosome 22 . Hum Genet 1989;84: $59-62$.

7 Gustavson KH, Arancibia W, Eriksson U, Svennerholm L. Deleted ring chromosome 22 in a mentally retarded boy. Clin Genet 1986;29:337-41. 